Dunamis: Jurnal Teologi dan Pendidikan Kristiani

Volume 3, Nomor 1 (Oktober 2018)

ISSN 2541-3937 (print), 2541-3945 (online)

http://www.sttintheos.ac.id/e-journal/index.php/dunamis

\title{
Persinggungan Agama dan Politik dalam Teror: Menuju Terbentuknya Teologi Spiritualitas Politik dalam Konteks Maraknya Terorisme di Indonesia
}

\author{
Paulus Eko Kristianto \\ Sekolah Tinggi Filsafat Driyarkara Jakarta \\ paulusekokristianto@gmail.com
}

\begin{abstract}
This article tries to explore the theological model of political spirituality in the context of terrorism in Indonesia. This search is done using the literature study method. In the process, the authors found that each age has a pattern or model of theology of their respective political spirituality. But in the present, by elaborating on the results of literature studies and paying attention to the context of terrorism in Indonesia and the historical journey of theological view of political spirituality in the church, the author shows that we need to pay attention to the five foundations of political spirituality theology, namely to realize a secular faith, promote moral values and political mediation, love justice and peace, serve the public interest, rule through service and love. These five foundations are expected to respond to various terrorism in Indonesia.
\end{abstract}

Keywords: theology; spirituality; political; terrorism; radicalism; Indonesia

\begin{abstract}
Abstrak
Artikel ini mencoba menelusuri model teologi spiritualitas politik dalam konteks maraknya terorisme di Indonesia. Penelusuran ini dilakukan dengan menggunakan metode studi pustaka. Dalam prosesnya, penulis menemukan bahwa setiap zaman memiliki corak atau model berteologi spiritualitas politiknya masing-masing. Namun pada masa sekarang, dengan mengelaborasi hasil studi pustaka dan memperhatikan konteks terorisme di Indonesia serta perjalanan sejarah pandang teologi spiritualitas politik di gereja, penulis menunjukkan kita perlu memperhatikan lima fondasi teologi spiritualitas politik yaitu mewujudkan iman yang sekular, mengusung nilai-nilai moral dan mediasi politik, mencintai keadilan dan perdamaian, mengabdi kepentingan umum, berkuasa melalui pelayanan dan kasih. Kelima fondasi ini diharapkan dapat menanggapi berbagai terorisme di Indonesia.
\end{abstract}

Kata Kunci: teologi; spiritualitas; politik; terorisme; radikalisme; Indonesia 


\section{PENDAHULUAN}

Maraknya aksi terorisme dengan banyaknya pengeboman membuat kehidupan Kristiani dipertanyakan. Ledakan aktual terjadi di Surabaya. Ledakan bom terjadi di tiga gereja (Gereja Katolik Santa Maria Tak Bercela di Jalan Ngagel Madya Utara, Gereja Kristen Indonesia di Jalan Diponegoro 146, dan Gereja Pantekosta Pusat Surabaya di Jalan Arjuna) di Surabaya. Akibat ledakan ini, dua orang meninggal dunia dan 13 orang mengalami luka. Berpijak pada situasi demikian, pertanyaan reflektif yang dapat diajukan yaitu bagaimana model teologi spiritualitas politik yang dapat dikembangkan? Pertanyaan reflektif ini menjadi penuntun penulisan artikel ini.

\section{METODE PENELITIAN}

Artikel ini ditulis mengacu pada hasil penelitian dengan menggunakan metode studi pustaka. Penulis menggali berbagai informasi tentang radikalisme, terorisme, dan teologi spiritualitas politik dari buku-buku.

\section{ANALISIS DAN HASIL PENELITIAN}

Radikalisme dan Terorisme di Indonesia: Persinggungan Agama dan Politik

Bila ditelusuri, hampir setiap masjid kampus di seluruh Indonesia, khususnya kampus-kampus terkemuka di Indonesia, seperti UI, IPB, dan ITB, dikuasi oleh mahasiswa-mahasiswa radikal dan mereka berhasil menduduki hampir semua posisi penting dalam organisasi kemahasiswaan intra-universitas (BEM, dll) di kampus-kampus itu. ${ }^{1}$ Rekrutmen untuk memperluas simpatisan dan menambah anggota ditujukan khususnya pada mahasiswa baru dan dilakukan selama masa Pekan Orientasi Studi Mahasiswa (POSMA) dan masa bimbingan. Selain itu, perluasan dan perekrutan dilakukan juga di sekolahsekolah lanjutan atas. Gambaran betapa meluasnya pengaruh radikalisme di kalangan pelajar SMP dan SMA sekarang ini dipaparkan oleh Prof. Dr. Bambang Pramono (dosen dan peneliti UIN Jakarta).

Radikalisme di Kalangan SMP dan SMA ${ }^{2}$

\begin{tabular}{|c|c|c|}
\hline Isu & $\begin{array}{c}\text { Siswa } \\
\text { SMP- } \\
\text { SMA }\end{array}$ & $\begin{array}{c}\text { Guru } \\
\text { Agama } \\
\text { Islam }\end{array}$ \\
\hline $\begin{array}{c}\text { Bersedia ikut } \\
\text { aksi kekerasan } \\
\text { terkait agama } \\
\text { dan moral }\end{array}$ & $48,90 \%$ & $28,20 \%$ \\
\hline Bersedia ikut & & \\
penyegelan/ & $41,10 \%$ & $22,70 \%$ \\
\hline
\end{tabular}

\footnotetext{
${ }^{1}$ Sarlito Wirawan Sarwono, Terorisme Di Indonesia Dalam Tinjauan Psikologi (Tangerang: Pustaka Alvabeth, 2012), 86-87.

${ }^{2}$ Ibid.
} 


\begin{tabular}{|c|c|c|}
\hline $\begin{array}{c}\text { perusakan } \\
\text { rumah/ fasilitas } \\
\text { milik agama lain }\end{array}$ & & \\
\hline $\begin{array}{c}\text { Membenarkan } \\
\text { aksi bom oleh } \\
\text { Imam Samudra, } \\
\text { Amrozi, } \\
\text { Noordin M. Top }\end{array}$ & $14,20 \%$ & $7,50 \%$ \\
\hline $\begin{array}{l}\text { Setuju syariat } \\
\text { Islam } \\
\text { diberlakukan }\end{array}$ & $84,80 \%$ & $76,20 \%$ \\
\hline $\begin{array}{c}\text { Pancasila tidak } \\
\text { relevan menjadi } \\
\text { dasar negara }\end{array}$ & $25,80 \%$ & $21,10 \%$ \\
\hline
\end{tabular}

Gambaran di atas menunjukkan bahwa siswa sekolah lanjutan pada khususnya dan mahasiswa serta generasi muda pada umumnya merupakan ladang yang subur untuk pengembangan radikalisme di Indonesia. Jika sampai 2005 aktivitas terorisme masih terbatas pada kalangan tertentu (jalur Afghanistan dan seterusnya), besar kemungkinan sejak 2009 dan seterusnya terorisme akan dilaksanakan oleh generasi baru yang tidak terkait langsung secara organisatoris dengan pelaku-pelaku generasi pertama, seperti yang sudah terbukti pada Ibrahim, Muhammad Syarif, dan Pepi. ${ }^{3}$ Di Indonesia, garis kekerasan diawali sejak S.M. Kartosuwiryo memproklamasikan berdirinya Negara Islam Indonesia (NII) yang disebut juga Darul Islam (DI) pada 7 Agustus 1949. ${ }^{4}$ Dengan berbagai alasannya sendiri, proklamasi Kartosuwiryo yang awalnya merupakan ekspresi kejengkelan atas perlakuan tidak adil pemerintahan Soeharto mendapat dukungan di beberapa tempat lain di Indonesia, termasuk di Sulawesi Selatan (Kahar Muzakar), Aceh (Daud Beureuh), dan Jawa Tengah (Amir Fattah). ${ }^{5}$

Sebagai alat kelengkapan negara NII (DI), dibentuklah Tentara Islam Indonesia (TII) yang kemudian menjadi alat perlawanan terhadap pemerintah RI yang sah di bawah Presiden Soekarno. Kartosuwiryo sendiri kemudian memilih garis keras melawan pemerintah. Maka, di Sulawesi Selatan, Aceh, dan Jawa Tengah terbentuk juga DI/TII. ${ }^{6}$ Di sisi lain, penganut NII yang tidak mengangkat senjata mempunyai dua pilihan yaitu berjuang untuk menegakkan syariat Islam lewat jalan formal dan legal yaitu mendirikan partai politik (dulu Masyumi dan PPP, sekarang PKS) dan berjuang melalui jalur parlemen. Pilihan yang lain yaitu memperbesar jumlah massa dan meluaskan daerah kekuasaan dengan cara

\footnotetext{
${ }^{4}$ Abdul Munir Mulkhan and Bilveer Singh, Demokrasi Di Bawah Bayangan Mimpi N-11 (Jakarta: Kompas, 2011), 34.

${ }^{5}$ Ibid.

${ }^{6}$ Sarwono, Terorisme Di Indonesia Dalam Tinjauan Psikologi, 92.
} 
merekrut dan membaiat pengikut-pengikut baru. Mereka inilah yang akhir-akhir ini banyak terungkap melalui media massa.

Bila ditelusuri, Sarlito W. Sarwono memetakan ciri-ciri individu dan kelompok yang sudah terpengaruh oleh ideologi radikal dalam delapan hal yaitu ${ }^{7}$ (1) benci pada pemerintah Indonesia karena tidak menjalankan syariat Islam; (2) menolak menyanyikan lagu Kebangsaan Indonesia Raya dan memberi hormat kepada bendera Merah Putih; (3) ikatan emosional kelompok mereka lebih kuat daripada ikatan emosional dengan keluarga/kampus/lingkungan kerja; (4) pengajian dan kaderisasi tertutup di lorong-lorong/sudut-sudut kampus/kantor (isolasi diri); (5) harus membayar sejumlah uang yang cukup besar secara berkala untuk disetorkan kepada organisasi untuk menebus dosa-dosa masa lalu; (6) berpakaian khas (katanya sesuai ajaran Islam); (7) umat Islam di luar kelompok adalah fasik dan kafir sebelum hijrah (bergabung dengan mereka); dan (8) enggan mendengarkan ceramah di luar kelompoknya walaupun pengetahuannya tentang Islam masih sangat terbatas.

Berbagai upaya terus dilakukan pemerintah guna mengatasi terorisme. Setidaknya, ada beberapa hal yang patut kita apresiasi dari kinerja pemerintah.
Sarlito W. Sarwono memetakan tiga faktor yang menyebabkan keberhasilan Polri dalam mengendalikan terorisme di Indonesia yaitu $^{8}$

1. Para pelaku berasal dari jaringan yang sama. Semuanya berawal dari kelompok Abdullah Sungkar dan Abu Bakar Baasyir, pendiri Pondok Pesantren Ngruki, Solo, dan mantan aktivis Darul Islam/Tentara Islam Indonesia (DI/TII) yang pada tahun 1982 melarikan diri ke Malaysia untuk menghindari penangkapan oleh Pemerintah Soeharto. Dari Malaysia, mereka bergabung dengan para Mujahidin Afgahanistan yang sedang berperang melawan penjajahan Rusia. Di sinilah terjadinya kontak dengan Osama bin Laden dan organisasinya, al-Qaeda. Mereka kemudian mengirimkan sejumlah pemuda untuk dididik di Akademi Militer Afghanistan yang sekaligus terlibat dalam perang jihad melawan Rusia. Pada 1993, Abdullah Sungkar dan Abu Bakar Baasyir (ABB) mengumumkan berdirinya Jamaah Islamiah. Pasca meninggalnya Abdullah Sungkar (1999), ABB kembali ke Ngruki karena situasi di Indonesia pascaSoeharto (era reformasi) sudah lebih

\footnotetext{
${ }^{8}$ Ibid, $78-84$.
} 
kondusif untuk melanjutkan perjuangan tanpa ancaman ditangkap oleh pemerintah. Dari Ngruki ABB yang saat itu menjadi Amir J1 melanjutkan operasi terornya melawan pemerintah Indonesia.

2. Jumlah yang terbatas itu tidak bertambah dengan cepat karena memang kelompok radikal ini tidak mencerminkan aspirasi mayoritas umat Islam di Indonesia. Mereka merupakan Muslim minoritas yang menyendiri dan tidak membaur dengan masyarakat umum di Indonesia. jika ada yang tertangkap atau tewas, para tetangga dan kerabat pun tidak tahu-menahu, bahkan cenderung menolak jenazahnya dimakamkan di lingkungannya. Bila dihitung secara statistik, hasil pemilihan umum menunjukkan bahwa sejak pemilu pertama pada tahun 1955 sampai 2009, perolehan partai-partai Islam menurun terus dari 43,72\% pada tahun 1955 hingga $27,29 \%$ pada $2009 .{ }^{9}$ Hasil statistik ini menunjukkan betapa masyarakat Indonesia merasa tidak terwakili oleh partai-partai politik Islam, terlebih lagi oleh kelompok-kelompok radikalis dan teroris. Bahkan hingga kini, organisasi besar Islam
(Muhammadiyah, Nahdlatul Ulama, dan Majelis Ulama Indonesia bersikap negative terhadap radikalisme dan terorisme. Hal ini berbeda sekali dengan Palestina dan Irak. Di kedua negara tersebut, semua warga laki-laki adalah mujahid dan siap mati syahid untuk membela agamanya. Di Palestina, mereka melawan Zionis zalim Israel, sedangkan yang Sunni di Iraq siap berjihad melawan Syiah, sebaliknya yang Syiah siap mati untuk menghancurkan Sunni. Di negara tersebut dapat dikatakan agama telah bercampur dengan politik dan kekuasaan.

3. Keberhasilan Polri dalam mengendalikan terorisme Indonesia merupakan kecanggihan polisi Imdonesia sendiri, khususnya Densus 88/AT (Detasemen Khusus 88/Anti-Teror) sebagaimana pengembangan dari Satgas (Satuan Tugas) Bom yang dibentuk segera setelah Bom Bali I. Pendekatan budaya yang dilakukan Densus 88 ketika menginterogasi dan menangani tangkapannya. Walaupun tetap dijaga ketat, tersangka teroris tidak diperlakukan buruk, bahkan keluarga disantuni. Teknik wawancara khusus pun 
dikembangkan yaitu dengan memanfaatkan adat budaya mereka seperti saling memanggil dan sebutan teman, berpelukan, dan saling mencium pipi dan seterusnya guna mencairkan komunikasi sehingga informasi dapat diperoleh dengan mudah. Kemampuan lain yang dikembangkan oleh Polri yaitu Teknik penyidikan, penyelidikan, dan penindakan hukum terhadap penyalahgunaan jaringan telepon dan internet. Dengan berhasilnya dikembangkan teknologi kontra cyber crime oleh Polri, banyak persembunyian teroris yang dapat diidentifikasi, pelakunya ditangkap, dan dapat ditindak secara hukum.

\section{Motivasi Keterlibatan dalam Terorisme}

Ada berbagai macam motivasi berbeda yang dapat membuat seseorang terlibat dalam terorisme, mulai dari sekadar ikut-ikutan untuk membantu teman tanpa mengetahui apa yang sebenarnya terjadi, sampai pada jihad ekstrem yang sesungguhnya, yang rela mengorbankan jiwa bagi kemenangan Islam. $^{10}$ Kebanyakan dari mereka bermula hanya karena didorong keingintahuan. ${ }^{11}$ Beberapa

${ }^{10}$ Ibid, 46.

${ }^{11}$ Pauline G. M. Aarten, Eva Mulder, and Antony Pemberton, "The Narrative of Victimization and Deradicalization: An Expert View," Studies in Conflict \& Terrorism 41, no. 7 (July 3, 2018): 557- hanya karena ingin mengenal Islam lebih jauh sehingga mereka bergabung dengan kelompok belajar Islam di sekolah, universitas, atau lingkungan sekitarnya. Bagaimanapun, terlepas dari perbedaan motivasi, terdapat kesamaan di antara para subyek. $^{12}$ Mereka semua ingin memperbaiki keadaan, yang mereka anggap sebagai tidak adil dan tidak sejalan dengan ajaran Islam. Pemerintah pada umumnya dituduh tidak adil pada Islam, dan cara mereka menjalankan negara dinilai tidak Islami. $^{13}$ Mereka melihat Islam secara hitam putih, antara baik dan buruk. Mereka memaknai al-Quran dan hadis secara literal dan tekstual, dan ingin mengimplementasikannya tanpa mempertimbangkan konteks sosial dan budaya. Oleh karenanya, jihad dianggap penting untuk memperbaiki situasi negara. Dan jihad, sebagaimana yang mereka pahami sebelum mereka ditangkap, dipandang untuk memerangi mereka yang non-Islam dan pemeluk Islam yang tidak

572, accessed October 12, 2018, https://www.tandfonline.com/doi/full/10.1080/1057 610X.2017.1311111.

${ }^{12}$ Javier Argomaniz and Orla Lynch, "Introduction to the Special Issue: The Complexity of Terrorism-Victims, Perpetrators and Radicalization," Studies in Conflict \& Terrorism 41, no. 7 (July 3, 2018): 491-506, accessed October 12, 2018, https://www.tandfonline.com/doi/full/10.1080/1057 610X.2017.1311101.

${ }^{13}$ Abdul Razak Baginda and Peter Schier, Terorism \& Sustainable Development (Asean Academic Pr Ltd, 2005), 40. 
mempraktikkan Islam sesuai hukum Syariah. $^{14}$

Secara kognitif, para subyek dapat dikatakan memiliki pemikiran yang dangkal. Beberapa dari mereka pun memiliki pendidikan yang terbatas dan hampir tidak ada pengalaman di luar komunitasnya. $^{15}$ Para subyek tidak memiliki pengetahuan pembanding. Bahkan, subyek yang lebih terdidik (sebagian dari mereka memiliki gelar akademik) tidak menunjukkan tanda-tanda memiliki pikiran yang luas. Oleh karena itu, yang dapat mereka lakukan hanyalah berpegang pada ajaran Islam monolitik yang telah diajarkan ustadz mereka di pesantren. Meskipun beberapa dari mereka pernah mengalami bepergian ke tempattempat lain, hubungan sosial mereka terbatas pada jaringan tertentu yaitu orangorang yang radikal itu sendiri. Tidak hanya sisi kognitif, kebanyakan dari subyek berasal dari kelas ekonomi menengah ke bawah tanpa pekerjaan permanen. Mereka membutuhkan status untuk mengingkatkan harga diri mereka dan status tersebut hanya dapat diperoleh melalui kelompok tertentu yang mereka pahami identik dengan kelompok fundamentalis. Bagi mereka, kelompok ini dinilai akan lebih diakui, lebih jelas definisinya, dan menjadi lebih

\footnotetext{
${ }^{14}$ Sarwono, Terorisme Di Indonesia Dalam Tinjauan Psikologi, 47.

${ }^{15}$ Ibid, 48
}

tinggi apabila mereka bergabung dengan kelompok yang dapat mengimplementasikan hukum Syariah di Indonesia. ${ }^{16}$

\section{Rasionalisasi di Balik Kekerasan}

Bagi para subyek, Islam bukanlah semata-mata sebagai agama, tetapi referensi bagi kehidupan sehari-hari, termasuk politik. Bahkan, mereka juga memahami Islam sebagai ideologi. Mereka kurang memikirkan adanya agama lain di Indonesia. Hal ini dikarenakan mereka hanya menghayati negara ini harus diatur secara Syariah. Mereka mengacu pada era kepemimpinan Nabi Muhammad ketika beliau memerintah Madinah di bawah Perjanjian Madinah di mana pemeluk Islam dan non-Islam dapat hidup berdampingan secara damai dan bahagia. ${ }^{17}$

Beberapa ayat al-Quran dan hadis nabi diinterpretasikan sebagai konfirmasi atas status halal untuk menghukum kebatilan, bahkan untuk mencuri dan membunuh mereka yang berlawanan dengan Islam. ${ }^{18}$ Pemerintah dinilai tidak serius dalam menghentikan kebatilan sehingga harus digantikan oleh pemerintah yang Islami. Doktrin "perang global" mengatakan bahwa selalu ada perang konstan yang terjadi antara Islam dan non-

\footnotetext{
${ }^{16}$ Ibid, 48-49.

${ }^{17}$ Ibid, 54.

${ }^{18}$ Ibid, 53.
} 
Islam di mana yang non-Islam akan terus menyerang kaum Islam untuk membuat mereka menjadi lemah. ${ }^{19}$ Tidak hanya itu, pemikiran bahwa selalu ada upaya dari orang-orang Barat yang disponsori oleh Amerika untuk menekan Islam. Para penjajah ini enggan berkompromi dan mengupayakan perdamaian sehingga satusatunya jalan untuk mencegah mereka adalah dengan memerangi mereka. Hukum Syariah harus ditegakkan dengan cara apapun. $^{20}$ Kekerasan adalah salah satu jalan yang dapat digunakan.

\section{Identitas Kristiani yang Tunggang}

\section{Langgang}

Kata "tunggang langgang" lebih cocok dimaknai berlarian tanpa arah. Dalam kehidupan sehari-hari, tunggang langgang digambarkan orang yang lari dikejar anjing sehingga orang tersebut berlarian tanpa arah. Berpijak pada maraknya terorisme, pertanyaan teologis yang muncul yaitu bagaimana dengan identitas Kristiani? Mengapa umat Kristiani kerap menjadi sasaran teror? Pencarian identitas ini tidak boleh dicari pada alam spiritual yang dianggap lepas

\footnotetext{
${ }^{19}$ Ibid.

${ }^{20}$ Elizabeth Shakman Hurd, "Politics of Religious Freedom in the Asia-Pacific: An Introduction," Journal of Religious and Political Practice 4, no. 1 (January 2, 2018): 9-26, accessed October 12, 2018, https://www.tandfonline.com/doi/full/10.1080/2056 6093.2017.1393172.
}

dari dunia, tetapi justru di tengah-tengah dunia, di bumi di sekitar yang konkrit ini. ${ }^{21}$ Sebaliknya, bila identitas Kristiani hanya berpusat di ranah spiritual saja tanpa masuk ke dunia nyata, maka keadaan yang terjadi yaitu identitas Kristiani yang tunggang langgang ketika mengalami masalah, di antaranya terorisme. Dengan kata lain, identitas Kristiani yang tunggang langgang berarti kondisi kekristenan yang lari tanpa arah karena mereka tidak siap menghadapi masalah.

Iman pada Yesus Kristus yang tersalib merupakan iman yang membumi. ${ }^{22}$ Hal ini sebenarnya sudah cukup disadari oleh sebagian besar para pengikut tradisi protestan. Tradisi ini amat membumi dan sering kali mengambil alih banyak tandatanda dari luar dunia sekuler. Orang Protestan tidak terlalu menyukai ritualisme religius, tetapi semua orang juga tahu bahwa ritualisme bukan merupakan sebuah hal sepele, melainkan ada ideologi yang kuat di belakangnya yang menjelaskan

\footnotetext{
${ }^{21}$ Emanuel Gerit Singgih, Iman \& Politik Dalam Era Reformasi Di Indonesia (Jakarta: BPK Gunung Mulia, 2000), 3.

${ }^{22}$ Iza Hussin, "'The New Global Politics of Religion': Religious Harmony, Public Order, and Securitisation in the Post-Colony," Journal of Religious and Political Practice 4, no. 1 (January 2, 2018): 93-106, accessed October 12, 2018, https://www.tandfonline.com/doi/full/10.1080/2056 6093.2017.1393173.
} 
identitas seseorang atau sebuah kelompok. $^{23}$

Dalam rangka menunjukkan identitas Kristiani di tengah persinggungan agama dan politik, E. Gerrit Singgih memetakannya dalam empat hal yaitu konfesionalisme dan/atau denominasionalisme, etnisisme, sekularisme, dan etatisme. ${ }^{24}$

\section{Konfesionalisme}

dan/atau

\section{denominasionalisme}

Di dalam paham ini, Kristus yang tersalib keliru diidentikkan dengan warna ajaran. Maka, yang menentukan di dalam persekutuan orang percaya bukan lagi persekutuan di sekitar salib dan penderitaan Kristus, melainkan kesetiaan pada ajaran yang bersifat mutlak. ${ }^{25}$ Tradisi kita di Indonesia sering tanpa sadar memutlakkan ajaran mengenai Kristus dan Injil sebagai Kristus dan Injil. Sering kali, kita juga mendengar orang mengubah panggilan atau ajakan Kristus kepada manusia untuk mengikuti Dia, menjadi mengikuti ajaran-Nya, yang dalam praktik berarti ajaran-ajarannya. Satu set atau sistem ajaran ini menjadi identitas yang tidak dapat ditawar-tawar lagi. Sebagai contoh, ajaran baptisan kerap dipakai sebagai ukuran mutlak untuk identitas.

\footnotetext{
${ }^{23}$ Singgih, Iman \& Politik Dalam Era Reformasi D $i$ Indonesia, 3.

${ }^{24}$ Ibid, 3-5.

${ }^{25}$ Ibid.
}

Akhirnya, gereja yang mengakui baptisan dewasa kerap tidak dapat berdampingan dengan gereja yang mengakui baptisan anak.

\section{Etnisisme}

Di dalam paham ini, Kristus yang tersalib keliru diidentikkan dengan warna etnis. Maka, yang menentukan dalam persekutuan orang percaya bukan persekutuan di sekitar salib dan penderitaan Kristus, melainkan identitas etnis (sukuisme atau nasionalisme). Memang tidak disebut "dewa", tetapi di dalam praktiknya etnisisme yang dimuliakan itu menjadi dewa secara tidak langsung. Etnisisme menjadi masalah. Di dalam Surat Galatia, Paulus menghadapi etnisisme Yahudi yang sudah terlanjur dianggap sebagai kriteria bagi iman. ${ }^{26}$ Bahkan, gereja dimungkinkan turut terbentengi oleh perkawinan antara konfesionalisme dan etnisisme.

\section{Sekularisme}

Dalam paham ini, Kristus yang tersalib keliru diidentikkan dengan warnawarni sekularisme. Hanya karena Paulus menentang ritualisme religius, maka orang Protestan yang ada di Indonesia cenderung mengambil-alih dan mempraktikkan komponen-komponen budaya sekular.

${ }^{26}$ Ibid. 
Tentu saja, masalah sekularisme lebih besar daripada sekadar melihat wujud luar. Yang menolak berelasi dengan Kristus yang tersalib sering kali adalah pribadi yang tidak dewasa, yang takut mengidentikkan diri dengan Kristus yang menderita dan lebih senang mengidentikkan diri dengan Kristus yang menderita dan lebih senang mengidentikkan dengan Kristus yang menang. Apabila manusia ditonjolkan sebagai kriteria kemenangan, hal itu berarti manusia tidak menjadi dewasa, tetapi menjadi dewa.

\section{Etatisme}

Dalam paham ini, Kristus yang tersalib keliru diidentikkan dengan berbagai struktur negara dan pemerintahan yang resmi. Etatisme ada kaitannya dengan sekularisme. Biasanya, badan yang melegitimasikan segala sesuatu di dalam sekularisme yaitu negara dan pemerintah juga. Tradisi Protestan yang anti ritualisme religius dan sampai batas tertentu juga dapat dikatakan anti berbagai wujud religi yang tradisional sehingga menjadi sangat mudah terjatuh pada etatisme. Maka, ada kecenderungan untuk mengidentikkan diri dengan negara dan siapa yang kebetulan sedang memerintah. Mereka menjadi berupaya menempel pada yang kuat, besar, dan pemberi legitimasi formal. Berbagai lambang dan nilai yang ada pada pemerintah dan negara cenderung diambilalih. Apabila negara bersifat sentralis, maka gereja juga cenderung sentralis juga.

Masalahnya, apabila terjadi teror, apakah berbagai ideologi tersebut masih berdiri sendiri-sendiri? Rasanya tidak. Semua ideologi identitas menjadi tunggang langgang. Lalu, bersatu menghadapi musuh bersama yaitu terorisme dan radikalisme. Rasanya, kita perlu mencari alternatif lain. Penulis menuangkan alternatif ini melalui spiritualitas politik.

\section{Memahami Spiritualitas Politik}

Kata "spiritualitas" sebagaimana dipahami dalam tradisi Kristiani mempunyai makna lebih dalam daripada hanya sekadar padanan dari kata "semangat" seperti lazim dipahami. Spiritualitas merujuk pada pengalaman hidup rohani. ${ }^{27}$ Ia menyangkut kehadiran Allah yang dialami orang beriman dalam relasi dengan-Nya. ${ }^{28}$ Namun sebagai catatan, spiritualitas tidak hanya bermakna demikian. Spiritualitas memiliki makna yang begitu luas sehingga ia turut merangkum segala bentuk kehidupan tanpa kepercayaan akan Allah seperti yang

\footnotetext{
${ }^{27}$ Arthur Holder, The Blackwell Companion to Christian Spirituality (Oxford: Blackwell Publishing, 2005), 16.

${ }^{28}$ Alister E McGrath, Christian Spirituality: An Introduction (Oxford: Blackwell Publishing, 1999), 19.
} 
diyakini Andre Comte Sponville. ${ }^{29}$ Dalam penulisan artikel ini, penulis menggunakan perspektif spiritualitas secara Kristiani, tentang relasi manusia dengan Allah atau yang Ilahi.

Kata "politik" dalam karya ini dipergunakan guna menunjuk berbagai dimensi keterlibatan warga gereja dalam ranah publik. Secara klasik, kata "politik" (politikos) merupakan kata sifat turunan dari kata Yunani "polis" (kota) guna mengungkapkan segala hal yang berkaitan dengan kehidupan kota. $^{30}$ Politik lalu dipahami sebagai pengetahuan secara menyeluruh atau terorganisir tentang segala hal yang berkaitan dengan negara. Politik kehilangan artinya yang asli dan menjadikan polis atau kota sebagai subyek. ${ }^{31}$ Hal ini membuat berkembangnya berbagai istilah contohnya ilmu tentang negara, ajaran tentang negara, atau filsafat politik. Namun dalam penulisan artikel ini, penulis menggunakan "politik" sebagaimana pada dokumen gereja Gaudium et Spes (GS). Dokumen ini menunjukkan politik turut mencakup hal khusus yakni keterlibatan langsung dalam politik praktis demi tercapainya kebaikan

\footnotetext{
${ }^{29}$ Paulinus Yan Olla, Spiritualitas Politik: Kesucian Politik Dalam Perspektif Kristiani (Jakarta: PT Gramedia Pustaka Utama, 2014), 15.

${ }^{30}$ Ibid, 16

${ }^{31}$ William Stringfellow, The Politics of Spirituality (Westminster: Westminster John Knox Press, 1984), 40-47.
}

umum (bonum comune). ${ }^{32}$ Keterlibatan langsung dilakukan oleh mereka yang secara aktif berperan dalam bidang legislatif, eksekutif, judikatif di tingkat nasional maupun daerah.

Merujuk pemaknaan kata "spiritualitas" dan "politik" di atas, kita dapat memahami kata "spiritualitas politik" mencakup wacana relasi antara spiritualitas dan perwujudannya secara umum oleh warga Kristiani biasa maupun yang terlibat dalam politik praktis melalui partai politik dan berbagai bidang publik pemerintahan. Bagi banyak orang, spiritualitas mungkin tidak ada hubungannya dengan politik. ${ }^{33}$ Politik tergolong urusan administratif yang rasional. Bahkan, bahasan spiritualitas politik kerap menjadi bahan cemoohan di kalangan sebagian politikus. Olla menunjukkan mereka yang melihat keterpisahan antara spiritualitas dan politik dimungkinkan memberi penekanan pada pengaturan kehidupan publik yang lebih berpedoman pada etika tanggung jawab. ${ }^{34}$ Bentuk politik kemudian dipertentangkan atau disalahartikan oleh sebagian orang

\footnotetext{
${ }^{32}$ Olla, Spiritualitas Politik: Kesucian Politik Dalam Perspektif Kristiani, 16.

${ }^{33}$ David B. Perrin, Studying Christian Spirituality (New York: Routledge, 2007), 40-46.

${ }^{34}$ Olla, Spiritualitas Politik: Kesucian Politik

Dalam Perspektif Kristiani, 20.
} 
berlawanan dengan etika keyakinan atau disebut juga etika absolut. ${ }^{35}$

Olla memetakan dalam apa yang disebut politik berbasis etika tanggung jawab, mereka yang menjadi politikus bertanggungjawab atas berbagai akibat yang muncul dari berbagai keputusannya. ${ }^{36}$ Hal terpenting dalam etika ini yaitu hasil yang diperoleh, suksesnya keputusankeputusan, berhasilnya pembuatan hukum, dan berbagai rencana yang membawa manfaat bagi kota atau negara ke masa depan. Di sisi lain, etika keyakinan memberikan penekanan pada aspek niat, maksud, atau intensi dalam pengambilan keputusan. $^{37}$ Bila kita mencoba mempertentangkan kedua bentuk etika tersebut, kita akan mendapati kesan seakan inspirasi Kristiani bersifat apolitis. Selain itu, jika pertentangan tersebut dilanjutkan, maka politik dapat meminggirkan sumbangan spiritualitas pada ranah kehidupan publik. Namun, di saat yang sama, politik pun dimungkinkan akan dijalankan tanpa jiwa. Dengan demikian, yang diperlukan yaitu keseimbangan untuk melihat kaitan antara kedua bentuk etika

\footnotetext{
${ }^{35}$ Atalia Omer, "When 'good Religion' Is Good," Journal of Religious and Political Practice 4, no. 1 (January 2, 2018): 122-136, accessed October 13, 2018,

https://www.tandfonline.com/doi/full/10.1080/2056 6093.2017.1396089.

${ }^{36}$ Olla, Spiritualitas Politik: Kesucian Politik

Dalam Perspektif Kristiani, 20.

${ }^{37}$ Ibid.
}

itu dalam pembicaraannya tentang kaitan antara politik dan spiritualitas. Spiritualitas politik yang mengalir dari iman diwujudkan dalam keterlibatan politik. Keterlibatan gereja sebagai institusi dan keterlibatan warganya menjadi suatu keniscayaan yang muncul dari pengalaman iman Kristiani.

\section{Panorama Spiritualitas Politik}

Sejak keberadaannya, gereja selalu menemukan diri dalam relasi sosial-politik. Sejarah jatuh bangunnya relasi tersebut banyak diuraikan dalam literatur sejarah gereja. Dinamika relasi tersebut membawa gereja belajar menemukan berbagai bentuk yang semakin lama mendekati idealisme sebagaimana yang diinspirasikan dari imannya. Secara sederhana, Paulinus Yan Olla memetakannya sebagai berikut. ${ }^{38}$

\section{Spiritualitas}

Politik

Zaman

\section{Penganiayaan}

Zaman awal Kekristenan ditandai situasi orang Kristiani sebagai sebuah kelompok minoritas. Mereka dapat dikatakan minoritas dalam lingkup agama Yahudi. Hal itu dikarenakan mereka dianggap hanya sebagai kelompok sempalan atau sekte Yahudi. Pada abadabad awal (abad pertama sampai ke-4), orang Kristiani juga mengalami

\footnotetext{
${ }^{38}$ Ibid, 23-36.
} 
penganiayaan. ${ }^{39}$ Zaman itu dapat dikatakan sebagai zaman kemartiran. Hal itu didukung adanya penolakan mereka untuk menyembah kaisar sebagai manifestasi kekuasaan ilahi. Legitimasi ilahi atas kekuasaan ditantang oleh sikap orangorang Kristiani yang menolak menjadikan kaisar seakan Tuhan. Orang Kristiani secara teratur menjadi obyek penyingkiran dan karenanya mereka pun menyingkir dari kehidupan sosial-politik. ${ }^{40}$

Dalam konteks ini, kekaisaran Roma terlihat membangun kekuasaan atas dasar legitimasi religius. Raja dipandang bagaikan titisan "Yang Ilahi" atau menganggap diri sebagai "tuhan". ${ }^{41} \mathrm{Hal}$ itu dimulai dengan kaisar Agustus, penyatuan fungsi Kaisar sekaligus Imam (Imperator Sacerdos), penolakan atas kaisar/raja yang dianggap tidak hanya sebuah tindakan makar, melainkan ungkapan ateis. Para martir Kristiani bersedia mengakui Kaisar sebagai penguasa politik, tetapi menolak mengakuinya sebagai Tuhan. $^{42}$ Bila petakan, ungkapan spiritualitas politik yang mengalir dari situasi penganiayaan ialah sikap kritis terhadap kekuasaan.

\footnotetext{
${ }^{39}$ Ibid.

${ }^{40}$ Oliver O'Donovan, From Irenaeus to Grotius: Sourcebook in Christian Political Thought (Grand Rapids: Eerdmans, 1999), 68-74.

${ }^{41}$ Olla, Spiritualitas Politik: Kesucian Politik

Dalam Perspektif Kristiani, 24.

${ }^{42}$ Oliver O'Donovan and John Lockwood

O'Donovan, Bond of Imperfection: Christian

Politics, Past and Present (Grand Rapids:

Eerdmans, 2004), 40.
}

Orang Kristiani yang terpinggirkan mengambil jarak dari kekuasaan dengan memberikan perlawanan kritis. Kritik itu muncul dari kesadaran nurani yang bersumber dari iman Kristiani yang menolak menyamakan manusia dengan Allah atau Tuhan pencipta. ${ }^{43}$

Dalam Citta di Dio (Kota Allah), Agustinus mengungkapkan pemikiran klasik politik Kristiani yang membedakan adanya dua bentuk pemerintahan. ${ }^{44}$ Kota atau pemerintahan manusia terbedakan dari kota atau pemerintahan Allah. Buku tersebut menunjukkan adanya tendensi negatif dalam memandang kekuasaan pemerintahan manusiawi. Dalam konteks demikian, orang Kristiani mengalami keterlibatannya dalam dunia hanya sebagai orang asing dan peziarah. Namun, ada juga kesadaran dominan bahwa mereka ada dalam dunia, tetapi tidak berasal dari dunia. Dengan demikian, perwujudan spiritualitas Kristiani terwujud dalam bentuk kritik terhadap kekuasaan sosialpolitik di zaman penganiayaan.

\section{Spiritualitas Politik Zaman Kekaisaran} dan Raja-Raja Kristiani

Situasi berubah dalam sejarah Gereja sejak tahun 313 ketika Kaisar

\footnotetext{
${ }^{43}$ Olla, Spiritualitas Politik: Kesucian Politik Dalam Perspektif Kristiani, 24.

${ }^{44}$ Ibid.
} 
Konstantinus menjadi Kristiani. $^{45}$ Pertobatan Kaisar mengubah panorama politik. Banyak orang yang duduk dalam pemerintahan mengikuti Kaisar beralih agama. Kristianitas yang semula terpinggirkan kini menjadi agama para pejabat negara. Dalam situasi sosial-politis itu, pandangan orang Kristiani tentang politik dan kekuasaan pun berubah. Kekuasaan politis yang dulu dipandang secara negatif kini dilihat sebagai sarana penyelamatan. Kekuasaan digunakan untuk mewartakan iman Kristiani. Agama yang dulu dianiaya berubah menjadi sarana kehormatan dan jalan kekuasaan.

Setelah periode kekaisaran, hubungan simbiosis antara kekuasaan dan agama Kristiani berlanjut pada periode raja-raja Kristiani di Eropa. Penobatan Karel Agung sebagai Kaisar Romawi Suci (Sacro Romano Impero) oleh Paus Leo III pada tahun 800 , menjadi titik awal periode raja-raja Eropa. ${ }^{46}$ Periode ini berlangsung bersamaan dengan hadirnya negara-negara Katolik dan terus berlangsung mulai dari akhir abad Pertengahan sampai beberapa tahun setelah Revolusi Prancis, 1789. Sayangnya, orang Kristiani di zaman ini kurang kritis berhadapan dengan kekuasaan dan politik. Hal itu terlihat dari (1) pengabdiannya terhadap kekuasaan dengan melegitimasi kekuasaan raja seakan kekuasaan Allah; (2) identifikasi gereja dengan kekuasaan politik sedemikian rupa sehingga mengaburkan pembedaan antara lingkup rohani dan politik; (3) pembenaran perang atau kekerasan melalui legitimasi keagamaan. ${ }^{47}$ Walaupun hubungan simbiosis antara gereja dan kekuasaan ini terkesan dominan, dalam gereja zaman itu, masih ada suara profetis yang tidak menerima sikap politis itu di antaranya berasal dari Ambrosius, Siprianus, Hildegardis dari Bingen, Fransiskus Assisi, Katarina dari Siena, Thomas More. $^{48}$ Mereka menyuarakan pemurnian spiritualitas Kristiani dan mempertanyakan pengaburan batas antara iman dan kekuasaan politik dengan cara hidup dan karya mereka. Meskipun adanya kritik tokoh suci dalam gereja zaman itu, spiritualitas politik yang paling dominan yaitu ketaatan dan pelayanan terhadap kekuasaan.

Spiritualitas Politik Zaman Revolusi Prancis dan Berakhirnya Kerajaan Kristiani

Masa 130 tahun antara Revolusi Prancis sampai akhirnya Kerajaan Habsburg di Austria 1918 merupakan masa berakhirnya Kekaisaran Romawi Suci dan

\footnotetext{
${ }^{47}$ Ibid, 26-27.

${ }^{48}$ Ibid, 27.
}

${ }^{45}$ Ibid, 25.
${ }^{46}$ Ibid, 26. 
raja-raja Kristianinya. ${ }^{49}$ Sejak Revolusi Prancis, semangat sekularisme terus tumbuh sampai berakhirnya kerajaan dan negara-negara Kristiani. Bersamaan dengan menguatnya sekularisasi kekuasaan politik, tumbuh kuat sikap antiklerikal dan antikatolisitas. $^{50}$ Segala yang berkaitan dengan gereja ditolak, termasuk harta dan milik gereja pun direbut. Tidak ada lagi raja-raja Kristiani yang menjadi pembelapembela iman (defensores fidei). Penganiayaan kembali dialami gereja hampir di seluruh Eropa. Selama sekitar 1.500 tahun, sejarah Kekristenan di Barat hanya mempunyai dua pelaku utama dalam politik. $^{51}$ Para Raja sebagai aktor politik dan gereja (Paus) sebagai pengawas keagamaan dan moral politik. Tugas itu diwujudkan dalam bentuk pendidikan dan moralisasi para raja dan lingkungan di sekitarnya.

Menghadapi situasi demikian, orang Kristiani mengambil sikap untuk bekerja sama atau menolak berpartisipasi dalam politik negara-negara sekular. Sebagai contoh, dekrit tidak baik/layak (non expedit) disuarakan oleh Paus Pius IX pada tahun 1874 yang berisi seruan agar

\footnotetext{
${ }^{49}$ Ibid, 28.

${ }^{50}$ Elizabeth Phillips, Political Theology (London: T \& T Clark, 2012), 68-82.

${ }^{51}$ William T. Cavanaugh and Jeffrey W. Bailey, $A n$ Eerdmans Reader on Contemporary Political Theology, ed. Craig Hovey (Grand Rapids: Eerdmans, 2012), 30.
}

orang Katolik di Italia tidak berpartisipasi dalam pemilihan umum maupun terlibat dalam kehidupan politik negara Italia. $^{52}$ Sikap penolakan demikian kemudian menyebar ke berbagai negara EropaKristiani meskipun dalam cara berbeda di setiap negara. Tidak hanya itu, Paus yang sama mengecam pula prinsip demokrasi dalam Daftar Kesalahan-kesalahan (Syllabbus Errorum) tahun $1864 .^{53}$ Bila dipetakan, spiritualitas politik yang dominan dalam periode ini yaitu sikap menarik diri dari kekuasaan politik, tetapi di saat yang sama ada usaha-usaha mengadakan mediasi. Dua sikap demikian akan berpengaruh selama abad ke-19 dan mewarnai usaha mencari relasi baru antara gereja dan masyarakat setelah berakhirnya masa para raja Kristiani.

\section{Spiritualitas Politik Sejak Konsili Vatikan}

\section{II sampai Sekarang}

Lahirnya berbagai negara demokratis memaksa gereja merumuskan kembali relasinya dengan kekuasaan dan politik. Gereja diminta senantiasa mencari jati dirinya di bidang keterlibatan sosial politiknya. Pengalaman pahit di masa lampau dan pembaruan yang terjadi dalam diri gereja telah mengembuskan arah baru bagi perwujudan sebuah spiritualitas

\footnotetext{
${ }^{52}$ Olla, Spiritualitas Politik: Kesucian Politik Dalam Perspektif Kristiani, 29.

${ }^{53}$ Ibid.
} 
baru. ${ }^{54}$ Bila dipetakan, salah satu langkah besar yang merangkum paham tersebut terlihat dalam berbagai keputusan Konsili Vatikan II. Salah satu dokumen yang mengungkapkan kesatuan gereja dengan masyarakat sosial politis yaitu Gaudium et Spes (GS) tahun $19655^{55}$ Spiritualitas Kristiani yang mengalir dari dokumen tersebut membumikan iman Kristiani dalam kenyataan hidup sosial-politik di mana gereja berada. Bila berpangkal dari Vatikan II dan refleksi selanjutnya melalui ajaran para Paus, Giampaolo Crepaldi, kita diajak memperhatikan beberapa langkah penting keterlibatan gereja dalam bidang politik di zaman neo-modernisme yang dapat dibedakan dalam beberapa periode yaitu resistensi, penantian, dan kebangkitan kembali. ${ }^{56}$

Pada periode resistensi (tahun 1960-1970), kita dapat melihat adanya sebuah perang budaya yang dilancarkan sekularisme modern melawan gereja. $^{57}$ Keadaan demikian membuat gereja menjadi ragu, terhentak, dan mengalami krisis diri dan misinya. Keterlibatan gereja dalam politik dipertanyakan, ajarannya dikecam, dan relasi antara gereja dan politik dipertanyakan manfaat serta validitasnya. Tidak hanya itu, periode ini

\footnotetext{
${ }^{54}$ Ibid, 30.

${ }^{55}$ Ibid.

56 Ibid.

${ }^{57}$ Ibid.
}

turut menguncang teologi. Pemikiran teologi gereja dianggap sebagai bentuk kekerasan terhadap kebenaran. Ungkapan Ernst Bloch tentang Allah mewakili mentalitas tersebut. Bagi Bloch, Allah digambarkan bukan "Dia sebagaimana adanya", tetapi adalah "Dia yang akan ada". ${ }^{58}$ Pola ini membuat identitas Allah lebih ditentukan oleh situasi dan bukan oleh iman yang diyakini.

Pada periode penantian (tahun 1980-1990), kita dapat menemukan adanya penegasan kembali Ajaran Sosial Gereja dalam hidup sosial-politik melalui figur Paus Yohanes Paulus II. ${ }^{59}$ Secara sistematis, Paus Yohanes Paulus II memberi tekanan kuat pada antropologi Kristiani sebagaimana tertuang dalam ajaran sosial gereja. Tekanan tersebut menunjukkan adanya kaitan antara iman Kristiani dan kebudayaan, relasinya dengan negara, serta keterlibatan gereja dalam pembelaan hak-hak asasi manusia. ${ }^{60}$ Konteks ini menunjukkan manusia telah diselamatkan dalam segala aspek kehidupannya, baik secara rohani maupun martabatnya di bidang sosial-politik. Melalui Ensiklik Fides et Ratio, kita melihat adanya penegasan tentang kebenaran sebagai suatu hal yang pokok dalam Kristianitas, sedangkan melalui

\footnotetext{
${ }^{58}$ Ibid, 31.

${ }^{59}$ Ibid.

${ }^{60}$ Ibid.
} 
Evangelium Vitae, kita melihat adanya pertahanan hak atas kehidupan sebagai dasar bagi keadilan dan hak-hak asasi manusia. ${ }^{61}$ Secara konkrit, dokumen ini mengungkapkan ajaran tentang moralitas perkawinan, seksualitas, dan prokreasi.

Melalui Veritatis Splendor, Yohanes Paulus II membendung berbagai paham moral yang menghalalkan berbagai cara untuk mencapai tujuan. Dokumen ini mencoba menegaskan pentingnya peran suara hati manusia dan berbagai cara yang layak demi pencapaian nilai-nilai dalam kehidupan secara bertanggungjawab. ${ }^{62}$ Melalui Centesimus Annus dan masuknya seluruh tradisi ajaran sosial gereja dalam Katekismus Gereja Katolik yang dirintis Yohanes Paulus II gereja menjadi semakin meneguhkan kehadirannya dalam bidang sosial-politik. ${ }^{63}$ Setelah tahun 1990 , secara perlahan, gereja mengokohkan diri untuk bangkit kembali dalam keterlibatan sosialpolitik. Salah satu tahap penting dalam peralihan itu yaitu Nota Doktrin dari Kongregasi untuk Ajaran Iman tahun 2002. ${ }^{64}$ Dokumen tersebut menegaskan adanya tuntutan moral dasar yang tidak dapat dinegosiasikan berhadapan dengan rezim relativisme moral dan kultural di bidang politik.

\footnotetext{
${ }^{61}$ Ibid, 32.

62 Ibid.

${ }^{63}$ Ibid.

${ }^{64}$ Ibid.
}

Periode kebangkitan kembali dapat dikatakan dipersiapkan oleh Yohanes Paulus II dan mencapai tahap perwujudannya dalam masa kepausan Benediktus XVI. ${ }^{65}$ Argumen utama yang dipertegas dalam masa ini yaitu kebenaran Kristianitas. Hal itu dilakukan karena adanya pemahaman bahwa relativisme filosofis telah menghasilkan relativisme agama yang pada ujungnya membawa sebuah spiral dekonstruksi yang pada hakikatnya bersifat nihilistis. Oleh karenanya, periode ini tidak semata mengandalkan akal budi, melainkan iman sebagai bantuan atau pencerah akal budi dalam pencarian kebenaran. Dalam periode ini, Kristianitas menemukan identitasnya dan semakin kuat menyadari adanya dimensi historis-sosial yang mengalir dari imannya. Kristianitas banyak berhadapan dengan diktator relativisme, dimensi publik dari iman Kristiani, pemurnian akal budi, menghindari bentuk berdialog tanpa kebenaran, toleransi tanpa kriteria, paham hukum moral, penyalahgunaan ide mesianisme tanpa Allah, moralisme politik, maupun koherensi pilihan politis orang beriman. ${ }^{66}$

Ketiga periode ini (resistensi, penantian, dan kebangkitan kembali) memperlihatkan transisi yang panjang

\footnotetext{
${ }^{65}$ Ibid.

${ }^{66}$ Ibid, 33.
} 
antara masa krisis yang dialami gereja setelah modernisme dan proses kebangkitan kembali kesadaran akan pentingnya keterlibatan publik. $^{67}$ Dalam posisi ini, Paus Benediktus XVI mengakui betapa perlunya keterlibatan agama dalam medan sosial-politik. Hal ini dikarenakan dalam politik kenegaraan semakin banyak politisi secara umum meminggirkan agama dari ranah publik. Adanya sikap anti agama dan nilai-nilai keagamaan bagi pembangunan sebuah bangsa. Paus Benediktus XVI menekankan pengingkaran warisan moral dan kerohanian agama-agama besar dunia dalam politik merupakan pula pengingkaran terhadap martabat manusia sendiri. ${ }^{68}$

$$
\text { Dalam perjalanan waktu }
$$

berikutnya, Paus Fransiskus menggantikan Paus Benediktus XVI. Langkah dan arah politik Paus Fransiskus ditampakkan dalam pertemuannya dengan korps diplomatis pada Jumat, 22 Maret 2013 di Vatikan. Dalam pertemuan dengan para duta besar yang terakreditasi untuk Takhta Suci Vatikan, Paus mengingatkan kembali misi utama Takhta Suci dalam politik. Ia menegaskan bahwa usaha yang dilakukan Vatikan dan semua negara yang bekerja sama dengannya ialah demi kebaikan

\footnotetext{
${ }^{67}$ Ibid, 34.
}

${ }^{68}$ Ibid. seluruh umat manusia. ${ }^{69}$ Guna mencapai kebaikan seluruh umat manusia, Paus menegaskan perlunya usaha bersama melawan kemiskinan, membangun perdamaian, dan membangun jembatan antarumat manusia. Selain itu, membangun perdamaian juga merupakan ajakan Paus. Tugas tersebut tidak dapat dilakukan tanpa landasan kebenaran. Paus Fransiskus meneruskan ajaran pendahulunya tentang berkembangnya diktator relativisme sebagai bentuk kehidupan manusia masa kini yang merujuk diri sendiri sebagai kebenaran. ${ }^{70}$ Yang kemudian berkembang dalam masyarakat yaitu usaha setiap orang untuk menuntut haknya tanpa keprihatinan akan hidup sesamanya.

\section{Menuju Terbentuknya Spiritualitas Politik}

Setelah melihat panorama spiritualitas politik, bagaimana model spiritualitas relevan dalam konteks maraknya terorisme? Meminjam bingkai Olla, penulis memetakannya dalam lima hal yaitu: ${ }^{71}$

\section{Mewujudkan Iman yang Sekular}

Orang Kristiani yang melibatkan diri dalam dunia dan kenyataan sosialpolitik patut menyadari bahwa salah satu

\footnotetext{
${ }^{69}$ Ibid, 35.

${ }^{70}$ Ibid, 36 .

${ }^{71}$ Ibid, 70-83.
} 
keyakinan dasar gereja yang mendorongnya untuk berpolitik mendapat dasarnya dalam ajakan Yesus untuk membedakan antara sikap terhadap kekuasaan dunia dan iman terhadap kekuasaan Tuhan. ${ }^{72}$ Pengakuan atas aspek sekular, profan, dan keterlibatan yang otonom dalam dunia memungkinkan orang beriman yang terlibat dalam politik tidak mengusung secara langsung kepentingan gereja. Hal ini tergambar ketika gereja bersama-sama bergandengan tangan menghadapi terorisme dan radikalisme. Semua tanpa dilakukan atas kepentingan gereja, melainkan mewartakan kasih Kristus yang mengampuni dan memulihkan.

\section{Mengusung Nilai-Nilai Moral dan Mediasi Politik}

Nilai-nilai moral ditundukkan oleh perhitungan dan kepentingan-kepentingan praktis. Politik memerlukan basis moral, tetapi perlu menghindarkan diri dari jebakan utopisme dan pragmatisme. $^{73}$ Utopisme politik perlu dihindari karena kendati ia menyimpan janji-janji yang bersifat abstrak dan tidak menyapa kehidupan konkrit manusia. Di sisi lain,

\footnotetext{
${ }^{72}$ Catherine Keller, Political Theology of the Earth: Our Planetary Emergency and the Struggle for a New Public (Insurrections: Critical Studies in Religion, Politics, and Culture) (Columbia: Columbia University Press, 2018), 78-80.

${ }^{73}$ Olla, Spiritualitas Politik: Kesucian Politik Dalam Perspektif Kristiani, 73.
}

pragmatisme politik memberi janji dan jaminan memenuhi berbagai kebutuhan konkrit, tetapi ia dapat mudah berubah menjadi machiavelisme dalam politik karena nilai-nilainya mudah ditukar dengan berbagai kepentingan praktis yang absen idealisme. Kedua jebakan itu dapat saling mengeksklusi maka perlu dihindari ketika nilai-nilai moral hendak diusung dalam politik. Oleh karenanya, ketika menghadapi terorisme, kita perlu membangun daya tahan menghadapi berbagai kenyataan sosial-politik yang sering berubah tanpa kendati. Perubahan yang cepat dan tanpa arah disertai dengan berbagai iming-iming kekuasaan dan harta yang dapat menutup mata politisi guna mengambil atau mendukung berbagai keputusan politik yang tuna nilai.

Dalam menghadapi terorisme, kita perlu menyadari bahwa iman bukanlah sebuah ideologi yang dapat diperdagangkan dalam tawar menawar politik. Hal ini dikarenakan ia menjadi inspirasi yang mendorong mereka untuk terlibat dalam politik guna mengambil berbagai tindakan nyata berdasarkan nilai Kristiani. Namun, kita perlu menyadari bahwa agama bukan berarti digunakan untuk membela institusi keagamaan dan kepentingan sektarian lainnya. Sikap terbuka untuk terus-menerus mencerna situasi berlandaskan iman memungkinkan 
kaum beriman yang terlibat dalam politik untuk ikut mengemban tanggung jawab membangun masyarakat berdasarkan kompetensi keimanan. Gereja tidak boleh tawar-menawar, seperti pembelaan kehidupan manusia sejak awal sampai akhir hidupnya, penggunaan kekerasan, maupun perang secara legitim. Semua argumentasi demikian bagi politisi menjadi medan mediasi guna menemukan suatu keputusan dan kebijakan publik secara bijaksana dan bertanggungjawab.

\section{Mencintai Keadilan dan Perdamaian}

Dalam spiritualitas, keadilan dan perdamaian yang diperjuangkan di politik disebut jalan kesucian hidup. ${ }^{74}$ Dalam perwujudannya, hal itu merupakan ajakan untuk menempatkan keadilan dan relasi harmonis antarmanusia sebagai bagian penting dalam politik. Inspirasi Kristiani tentang keadilan mendorong mereka yang terlibat dalam politik untuk mencari berbagai bentuk yang tepat dalam menciptakan masyarakat yang adil. Di sana, ada keprihatinan dan keberpihakan terhadap mereka yang terpinggirkan, yang miskin, dan yang hidupnya tidak layak dalam masyarakat. Perjuangan membebaskan mereka yang berada dalam situasi demikian melalui berbagai kebijakan politis yang memihak rakyat

\footnotetext{
${ }^{74}$ Ibid, 77.
}

kecil memperoleh inspirasi terdalamnya dalam sikap mencintai keadilan. Berkenaan dengan maraknya terorisme, mereka yang terlibat dalam politik perlu belajar mengatasi terorisme, mengolah ancaman sosial, dan mencari keseimbangan dalam menerima perbedaan pandangan politik ketika melihat terorisme.

\section{Mengabdi Kepentingan Umum}

Sepanjang sejarah, spiritualitas Kristiani berusaha menolong mereka yang menapak jalan kesucian guna melepaskan kepentingan diri sendiri agar mampu mencintai sesama dan Tuhan. Kulminasi dari sikap menanggalkan kepentingan diri yaitu tercapainya kerendahan hati. Dapat dibayangkan, spiritualitas demikian terasa sangat menegangkan bila melihat perjuangan yang umumnya dihadapi para politisi yakni persaingan untuk mendapat afirmasi diri. Yang diusung dalam persaingan antarpartai politik ialah penonjolan diri pribadi maupun kelompok. Terhadap kenyataan itu patut ditegaskan bahwa afirmasi diri dan usaha mewujudkan potensialitas diri merupakan kecenderungan alamiah dan sehat. Partaipartai politik dan politisinya memiliki berbagai agenda yang diusung. Hal ini memang dipandang wajar, tetapi dalam perspektif spiritualitas, afirmasi diri harus 
dikendalikan agar tidak menjadi hal yang paling penting dalam politik.

Tidak diragukan lagi bahwa setiap partai politik dan politisinya ingin menang, ingin mendapatkan penghargaan atas prestasi politik yang dicapainya. Namun, spiritualitas yang berbasis penanggalan kepentingan diri sendiri menantang mereka yang berkuasa untuk mengontrol diri agar tidak terjebak dalam pengabdian kekuasaan sebagai satu-satunya tujuan politik. $^{75}$ Dalam konteks maraknya terorisme, orang Kristiani tidak boleh mengatasi persoalan hanya berorientasi pada kepentingan diri, melainkan umum. Kewajiban menanggalkan kepentingan diri bagi orang Kristiani merupakan peringatan untuk memperluas cakupan persaudaraan dan kekeluargaan seperti diajarkan Yesus Kristus. ${ }^{76}$ Cakupan paham kekeluargaan semua orang. Dalam keterbukaan tersebut, hal yang menjadi ukuran persaudaraan yaitu kebenaran, kebaikan, dan kepentingan publik.

\section{Berkuasa Melalui Pelayanan dan Kasih}

Spiritualitas Kristiani mengajak orang beriman yang terlibat dalam politik untuk mengubah paham kekuasaan agar tidak berpusat pada diri sendiri. Telah lazim bahwa pejabat dan penguasa dunia dilayani. Inspirasi Kristiani tentang kekuasaan dilandaskan pada sikap dan ajaran Yesus yang menempatkan pemimpin sebagai pelayan. Bahkan lebih radikal, Yesus menuntut mereka yang berkuasa menjadi hamba untuk melayani bawahan dan seluruh kepentingan umum. ${ }^{77}$ Dalam konteks maraknya terorisme, pelayanan demikian tidak boleh hanya berpusat pada kelompok tertentu bila terjadi korban, melainkan semua tanpa terkecuali dengan semangat pelayanan dan kasih.

\section{KESIMPULAN}

Bila ditempatkan dalam menjawab pertanyaan "bagaimana model spiritualitas politik yang dapat dikembangkan?", artikel ini menunjukkan model tersebut perlu memperhatikan lima fondasi pemikiran yaitu mewujudkan iman yang sekular, mengusung nilai-nilai moral dan mediasi politik, mencintai keadilan dan perdamaian, mengabdi kepentingan umum, berkuasa melalui pelayanan dan kasih. Kelima fondasi ini dilakukan dengan memperhatikan konteks terorisme di Indonesia dan perjalanan sejarah pandang spiritualitas politik di gereja.

\section{REKOMENDASI}

\footnotetext{
77 John Howard Yoder, The Politics of Jesus (Grand Rapids: Eerdmans, 1994), 79-80.
} 
Setelah kita memperhatikan uraian model teologi spiritualitas politik di atas, penulis merekomendasikan bahwa pemikiran ini diharapkan menginspirasi gereja-gereja atau komunitas Kristiani lainnya guna menanggapi maraknya terorisme di Indonesia. Semua dilakukan bukan bermaksud untuk kekerasan, melainkan mengembangkan budaya damai.

\section{DAFTAR PUSTAKA}

Aarten, Pauline G. M., Eva Mulder, and Antony Pemberton. "The Narrative of Victimization and Deradicalization: An Expert View." Studies in Conflict \& Terrorism 41, no. 7 (July 3, 2018): 557-572. Accessed October 12, 2018. https://www.tandfonline.com/doi/full/ 10.1080/1057610X.2017.1311111.

Argomaniz, Javier, and Orla Lynch. "Introduction to the Special Issue: The Complexity of TerrorismVictims, Perpetrators and Radicalization." Studies in Conflict \& Terrorism 41, no. 7 (July 3, 2018): 491-506. Accessed October 12, 2018. https://www.tandfonline.com/doi/full/ 10.1080/1057610X.2017.1311101.

Baginda, Abdul Razak, and Peter Schier. Terorism \& Sustainable Development. Asean Academic Pr Ltd, 2005.

Cavanaugh, William T., and Jeffrey W. Bailey. An Eerdmans Reader on Contemporary Political Theology. Edited by Craig Hovey. Grand Rapids: Eerdmans, 2012.

Holder, Arthur. The Blackwell Companion to Christian Spirituality. Oxford: Blackwell Publishing, 2005.

Hurd, Elizabeth Shakman. "Politics of Religious Freedom in the AsiaPacific: An Introduction." Journal of
Religious and Political Practice 4, no. 1 (January 2, 2018): 9-26. Accessed October 12, 2018.

https://www.tandfonline.com/doi/full/ 10.1080/20566093.2017.1393172.

Hussin, Iza. "'The New Global Politics of Religion': Religious Harmony, Public Order, and Securitisation in the PostColony." Journal of Religious and Political Practice 4, no. 1 (January 2, 2018): 93-106. Accessed October 12, 2018.

https://www.tandfonline.com/doi/full/ 10.1080/20566093.2017.1393173.

Keller, Catherine. Political Theology of the Earth: Our Planetary Emergency and the Struggle for a New Public (Insurrections: Critical Studies in Religion, Politics, and Culture). Columbia: Columbia University Press, 2018.

McGrath, Alister E. Christian Spirituality: An Introduction. Oxford: Blackwell Publishing, 1999.

Mulkhan, Abdul Munir, and Bilveer Singh. Demokrasi Di Bawah Bayangan Mimpi N-11. Jakarta: Kompas, 2011.

O'Donovan, Oliver. From Irenaeus to Grotius: Sourcebook in Christian Political Thought. Grand Rapids: Eerdmans, 1999.

O’Donovan, Oliver, and John Lockwood O'Donovan. Bond of Imperfection: Christian Politics, Past and Present. Grand Rapids: Eerdmans, 2004.

Olla, Paulinus Yan. Spiritualitas Politik: Kesucian Politik Dalam Perspektif Kristiani. Jakarta: PT Gramedia Pustaka Utama, 2014.

Omer, Atalia. "When 'good Religion' Is Good." Journal of Religious and Political Practice 4, no. 1 (January 2, 2018): 122-136. Accessed October 13, 2018. https://www.tandfonline.com/doi/full/ 10.1080/20566093.2017.1396089. 
Perrin, David B. Studying Christian Spirituality. New York: Routledge, 2007.

Phillips, Elizabeth. Political Theology. London: T \& T Clark, 2012.

Sarwono, Sarlito Wirawan. Terorisme Di Indonesia Dalam Tinjauan Psikologi. Tangerang: Pustaka Alvabeth, 2012.

Singgih, Emanuel Gerit. Iman \& Politik Dalam Era Reformasi Di Indonesia.
Jakarta: BPK Gunung Mulia, 2000.

Spretnak, Charlene. The Politics of Women's Spirituality: Essays by Founding Mothers of the Movement. New York: Doubleday, 1982.

Stringfellow, William. The Politics of Spirituality. Westminster:

Westminster John Knox Press, 1984.

Yoder, John Howard. The Politics of Jesus. Grand Rapids: Eerdmans, 1994. 